J. Clin. Chem. Clin. Biochem.

Vol. 16, 1978, pp. 663-668

\title{
Improved Method for the Enzymatic Microdetermination of Cholesterol in Plasma Lipoproteins ${ }^{1}$ )
}

\author{
By M. Hoops ${ }^{2}$ ) and I. R. Kupke \\ Klinisch-chemisches Laboratorium, Universitäts-Kinderklinik \\ (Direktor: Prof. Dr. G.-A. von Harnack), Düsseldorf, Germany
}

(Received November 29, 1977/February 24/May 19, 1978)

Summary: An improved procedure for the quantitative enzymatic determination of cholesterol in the presence of agarose is reported. The agarose samples containing cholesterol are dried in vacuo and dissolved in $6 \mathrm{~mol} / 1 \mathrm{HCl}$. After neutralization, the cholesterol is determined enzymically. The reaction curve of this modified method is identical with that of the original serum method. A linear relationship is found in the range of $0.75-25.6 \mathrm{mmol} / 1 \mathrm{cholesterol}$. The coefficient of variation in the series is $<1.5 \%$ for cholesterol concentrations $>3 \mathrm{mmol} / \mathrm{l}$, while it is $<3 \%$ in the lower range. The $\mathrm{HCl}$ does not affect the ester bond of the cholesterol esters of the plasma samples. It is therefore possible to determine the free and the esterified cholesterol.

This modified procedure was applied to the enzymatic determination of cholesterol in the lipoprotein fractions of $15 \mu \mathrm{l}$ capillary plasma separated by electrophoresis on agarose gel. An improved electrophoretic procedure gave an excellent separation of the lipoprotein fractions of 16 plasma samples in a single run. The lipoprotein fractions are precipitated with dextran sulfate $/ \mathrm{CaCl}_{2}$, cut with a scalpel and dried in vacuo prior to dissolution with $6 \mathrm{~mol} / \mathrm{HCl}$. By drying the samples in vacuo, the loss of cholesterol, caused by drying them with filter paper, is avoided. The coefficients of variation in the series are as follows: $\beta$-lipoprotein cholesterol $<2 \%$, pre- $\beta$-lipoprotein cholesterol $4-6 \%, \alpha$-lipoprotein cholesterol 3-6\% for control and hyperlipidemic plasma samples. The recovery is $95-100 \%$.

The application of this procedure to the examination of 30 healthy children revealed that 7 had a cholesterol concentration $>4.66 \mathrm{mmol} / \mathrm{l}$. As in the remaining group of 23 children, this plasma cholesterol was predominantly localized in the $\beta$-lipoprotein fractions. The cholesterol contents of the $\alpha$ - and pre- $\beta$-lipoprotein fractions were not affected by the total cholesterol levels. No age dependence was found.

This preliminary study of a small group of children serves as a model for the large-scale examination of children of kindergarten age.

\section{Eine verbesserte Methode für die enzymatische Mikrobestimmung von Cholesterin in Plasma-Lipoproteinfraktionen}

Die enzymatische Bestimmung des Cholesterins in Gegenwart von Agarose konnte verbessert werden. Agaroseproben, welche bekannte Cholesterinmengen enthalten, werden in einem Exsiccator über Trockengel getrocknet und danach mit $6 \mathrm{~mol} / \mathrm{l} \mathrm{HCl}$ gelöst. In den neutralisierten Proben wird die enzymatische Cholesterinbestimmung vorgenommen. Die kinetischen Eigenschaften dieses modifizierten Vèrfahrens sind mit denjenigen der für das Serum-Cholesterin beschriebenen Referenzmethode vergleichbar. Die Linearität ist von $0,75-25,6 \mathrm{mmol} / \mathrm{l}$ Cholesterin gegeben. Die Präżision in der Serie ist $<1,5 \%$ für Cholesterinkonzentrationen $>3 \mathrm{mmol} / \mathrm{l}$ und $<3 \%$ im unteren Bereich. Die Cholesterinester werden durch die $\mathrm{HCl}$ nicht meß̣bar hydrolysiert. Eine Bestimmung des freien und veresterten Cholesterinn in dịesen Proben ist dạher möglich.

Dieses modifizieierte Verfahren wurde für die enzymatische Cholesterinbestimmung in Plasmalipoproteinen angewendet. Für die Trennung der Lipoproteine aus $15 \mu \mathrm{l}$ Kapillarplasma wird eine verbesserte Elektrophorese auf Agarosegel beschrieben. Die Lipoproteiñe von 16 Plasmaproben können gleichzeitig getrennt werden. Die Fraktionen werden durch eine Fällung mit Dextransulfat $/ \mathrm{CaCl}_{2}$ sichtbar gemacht, mit einem Skalpell geschnitten und in Plastik-Reagenzgläsern über Nacht im Exsiccator über Trockengèl getrocknet. Die beim Trocknen von Agarosegel-Pherogrammen mit Fịlterpapier entstehenden Cholesterinverluste können auf diese Weise vermieden werden.

1) Presented at the Tenth International Congress on Clinical Chemistry, February, 1978, Mexico City, Mexico.

2) Doctoral Thesis in Medicine. 
Die getrockneten Agarose-Lipoproteinproben werden mit $6 \mathrm{~mol} / \mathrm{l} \mathrm{HCl}$ gelöst und der Cholesteringehalt wird wie oben beschrieben bestimmt. Der Variationskoeffizient der Bestimmung ist $<2 \%$ für das $\beta$-Lipoprotein-Cholesterin, $4-6 \%$ für das prä- $\beta$ Lipoprotein-Cholesterin und 3-6\% für das $\alpha$-Lipoprotein-Cholesterin von Kontroll- und hyperlipidämischen Plasmaproben. 95-100\% des Cholesterins werden wiedergefunden.

Dieses Verfahren wurde für die Untersuchung von 30 gesunden Kindern angewendet. Bei 7 Kindern wurde ein Cholesteringehalt von $>4,66 \mathrm{mmol} / 1$ Plasma ermittelt. Diese erhöhte Cholesterinmenge wurde wie bei den übrigen $23 \mathrm{Kindern}$ von den $\beta$-Fraktionen transportiert. Der Cholesteringehalt der prä- $\beta$ - und $\alpha$-Lipoproteinfraktionen ließ keine Beeinflussung durch die Höhe des Gesamtcholesteringehaltes erkennen. Eine Altersabhängigkeit konnte nicht beobachtet werden.

Diese vorläufige Untersuchung einer kleinen Gruppe von Kindern dient als Modell für die Untersuchung von Kindern zahlreicher Düsseldorfer Kindergärten mit unterschiedlicher sozialer Struktur.

\section{Introduction}

The determination of the plasma lipoprotein cholesterol is widely used for diagnosis and therapeutic monitoring of disorders in lipid metabolism. It is an important tool in preventive medicine for the detection of abnormalities leading to atherosclerosis and coronary heart disease. A therosclerosis has been recognized as a pediatric problem (1-6) and early diagnosis in asymptomatic children may avert later ischemic heart disease (7). Accordingly, analytical procedures suitable for largescale preventive studies are required, especially in the pediatric field.

The methods available for this purpose were recently reviewed (8). Ultracentrifugation is not adequate for studies on a large-scale. Precipitation procedures and nomograms yield only approximate values. The extraction of cholesterol from hydrolyzed agarose samples followed by gas chromatography (9) is time consuming and, of course, depends on the availability of a gas chromatograph.

In the previous study (8), the enzymatic determination of cholesterol in the presence of agarose was described. Agarose samples containing cholesterol were dissolved with $\mathrm{HCl}$ and, after neutralization, the enzymatic determination of cholesterol according to Roeschlau et al. (10) was carried out. No influence of agarose and $\mathrm{HCl}$ on the enzymatic reactions was observed. The method was then applied to the determination of cholesterol in plasma lipoprotein fractions separated by electrophoresis on agarose gel. The precision in the series $(\mathrm{CV}, \%)$ was $<4 \%$ for the $\beta$-lipoprotein cholesterol of all types of plasma samples and $<8 \%$ for the pre- $\beta$-lipoprotein cholesterol of Type IV hyperlipidemic samples (8).

Because of the very low cholesterol concentrations in the other lipoprotein fractions, only an approximation could be achieved. However, the only requirements for this procedure are a common electrophoresis apparatus and a photometer.

The goal of the present study was to improve this method with respect to the reproducibility of the electrophoretic procedure, the recovery of cholesterol after the analytical steps, the precision of determination, and the suitability for routine analysis.

In a preliminary test, the modified method was applied to the examination of a small group of healthy children. This limited study was designed for the development of a model for large-scale investigations in the pediatric field.

\section{Materials and Methods}

Equipment

Corning-EEL/IMA D-6300 Gießen: Micro-electrophoresis system.

Boscamp/IL, D-5503 Hersel: Micro-electrophoresis

Zeiss, D-7082 Oberkochen: Spectrophotometer PM-4.

Eppendorf, D-2000 Hamburg: Rotation mixer.

Well former (fig. 1).

Chemicals

Serva, D-6900 Heidelberg: Agarose No. 11397; Nà-dextran sulfate 500, No. 18707; 5,5-Diethylbarbital sodium; EDTA$\mathrm{Na}_{2}$.

Behring, D-3550 Marburg: Crystalline bovine serum albumin.

Merck, D-6701 Darmstadt: Acetic acid, hydrochloric acid, sodium hydroxide, calcium chloride, $\mathrm{NH}_{4} \mathrm{H}_{2} \mathrm{PO}_{4}$ and $\left(\mathrm{NH}_{4}\right)_{2} \mathrm{HPO}_{4}, \mathrm{Na}_{2} \mathrm{CO}_{3}$, ethanol, glycerol (all chemicals p. a.), silica gel (blue gel), Sudan Black B.

Boehringer, D-6800 Mannheim: Biochemica Test Combination "Cholesterol" No. 15738, "Triglycerides" (Neutral Fat) No. 124966, Preciset Cholesterol, Precilip.

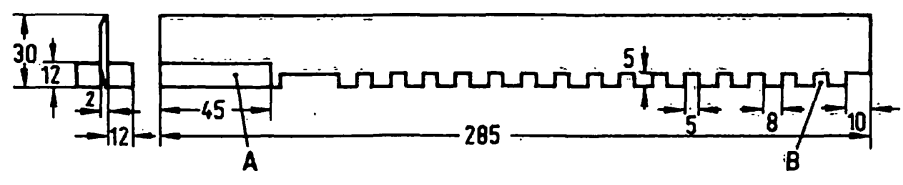

Fig. 1. Well former.

A plastic ruler with a $1 \mathrm{~mm}$ edge was cut to a length of $285 \mathrm{~mm}$.

A: At one end, the ruler was cemented with patex between disposible cuvettes $(12 \times 12 \times 45 \mathrm{~mm})$ in order to set it into an upright position.

B: With the help of a saw-blade, pieces of the ruler were sawed and broken out. The edges were smoothed with emery paper, if necessary. For 16 samples, the pieces were $5 \mathrm{~mm}$ wide, separated by a space of $8 \mathrm{~mm}$. 
Dade Div. American Hosp. Supply Corp., Miami, Fl. 33152: Lipid-trol, B 5129-5.

Sarstedt, D-5223 Nümbrecht-Rommelsdorf: Plastic tubes (polysty rol), $82 \times 16 \mathrm{~cm}$.

Greiner, D-5650 Solingen: Plastic tubes, vol. $1.8 \mathrm{ml}$.

Dupont de Nemours \& Co. Inc. (Wilmington, Delaware): Plastic sheets of Cronar Type P-7 R.

\section{Solutions}

$6 \mathrm{~mol} / 1 \mathrm{HCl}$ and $6 \mathrm{~mol} / 1 \mathrm{NaOH}$. The solutions should be adjusted to the point of equivalence.

Ammonium phosphate buffer, $5 \mathrm{~mol} / 1, \mathrm{pH} 7.6$.

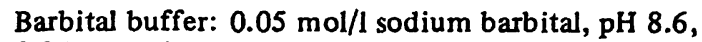
$0.94 \mathrm{mmol} / 1$ EDTA-Na 2 .

$\mathrm{Na}_{2} \mathrm{CO}_{3}$-glycerol solution: $0.06 \mathrm{~mol} / 1 \mathrm{Na}_{2} \mathrm{CO}_{3}, 0.05 \mathrm{~mol} / 1$ glycerol.

Dextran sulfate- $\mathrm{CaCl}_{2}$ solution: $6 \mathrm{~g} / \mathrm{l}$ dextran sulfate 500 , $0.33 \mathrm{~mol} / 1 \mathrm{CaCl}_{2}$.

Sudan Black solution: $0.5 \mathrm{~g}$ Sudan Black B are dissolved in $600 \mathrm{ml}$ ethanol and $400 \mathrm{ml}$ dist. water are added.

Bovine albumin solution: $100 \mathrm{~g} / 1$ dist. water.

\section{Electrophoresis}

A sheet of polyester film $(22 \times 15 \mathrm{~cm})$ was placed on a glass plate in such a way that the upper surface of the plastic was the inner surface on the plastic roll supplied by Dupont. It was heated at $100^{\circ} \mathrm{C}$ for $15 \mathrm{~min}$, which alleviated the tendency of the plastic sheet to curl during use. The glass plate and the film were kept at $50^{\circ} \mathrm{C}$. A few drops of water were put in the middle of the glass plate to keep the plastic sheet in position.

$0.6 \mathrm{~g}$ agarose was heated to boiling in $75 \mathrm{ml}$ barbital buffer. The solution was then cooled to $50^{\circ} \mathrm{C}$ in a water bath. $70 \mathrm{ml}$ of this agarose solution and $1 \mathrm{ml}$ of a bovine albumin solution at $50^{\circ} \mathrm{C}$ were mixed and poured onto the polyester film which was kept at $50^{\circ} \mathrm{C}$ on a level surface. Using a glass rod or a plastic tip, the agarose solution was spread over the entire surface of the film.

After 10 minutes, the slot former was placed in position (fig. 1). After a further 15 minutes, the solution had set into a gel, and was then transferred to the refrigarator at $4{ }^{\circ} \mathrm{C}$ for another $15 \mathrm{~min}$. The well former was taken out carefully and excess fluid was removed from the slots with a pipette connected to a suction pump.

A $50 \mu \mathrm{l}$ Hamilton syringe and the plasma samples were warmed in a water bath at $50^{\circ} \mathrm{C}$. The plasma samples were mixed with the agarose solution $1+1$ and $30 \mu$ l of these mixtures were applied to the agarose slots. The slots were then covered with agarose.

The polyester sheet with the agarose layer was transferred to the Boscamp-micorphor system dipping the edges into the buffer on both sides. The electrophoresis cell was kept in the refrigerator at $4{ }^{\circ} \mathrm{C}$. Separation of the lipoproteins was carried out at $150 \mathrm{~V}$ for 70 minutes.

\section{Localization of the lipoprotein fractions}

After electrophoresis, the agarose sheets were transferred to the dextran sulfate-CaCl ${ }_{2}$-solution (11) for 15 minutes. The lipoprotein fractions become visible by opalescence and they were cut with a scalpel. The agarose samples containing the lipoprotein fractions were transferred into plastic tubes $(82 \times 16 \mathrm{~cm})$ and they were dried for 6 hours in vacuo in a desiccator con taining blue gel.

\section{Staining of the lipoprotein fractions}

Alternatively, the film with the agarose layer was transferred to a $1.5 \mathrm{~mol} / \mathrm{l}$ acetic acid solution for 10 minutes followed by 30 minutes in the $\mathrm{Na}_{2} \mathrm{CO}_{3}$-gly cerrol solution. The samples were dried at $60^{\circ} \mathrm{C}$ for 60 minutes and stained with Sudan Black B for 30 minutes.
Enzy matic determination of cholesterol in the presence of agarose

$0.2 \mathrm{ml} 6 \mathrm{~mol} / \mathrm{l} \mathrm{HCl}$ were added to the dried agarose samples containing either known amounts of cholesterol standards (Preciset or Precilip) or the lipoprotein fractions obtained by electrophoresis. The samples were shaken vigorously on an Eppendorf shaker for 5 minutes and then placed in an ice bath $\left(0-4{ }^{\circ} \mathrm{C}\right) .0 .1 \mathrm{ml} 5 \mathrm{~mol} / \mathrm{l}$ ammonium phosphate buffer solution were added. After 3 minutes, each tube was taken out of the rack, dipped in the ice bath, and $0.2 \mathrm{ml} 6 \mathrm{~mol} / 1$ $\mathrm{NaOH}$ were added while the tube was carefully shaken. This careful shaking in the cold is necessary to prevent the appearance of greenish colored substances which inhibit the enzyme reactions. After complete cooling, the tubes were removed from the ice bath and $2.0 \mathrm{ml}$ of the reaction mixture (solution 5 of the Biochemica Test Combination "Cholesterol") were added. The samples were mixed, incubated at $37^{\circ} \mathrm{C}$ for 15 minutes and centrifuged at $3000 \mathrm{rpm}$ for 10 minutes. The supernatants were subjected to the oxidase reaction and measured against the corresponding sample blanks as described earlier $(8,10)$.

\section{Results and Discussion}

\section{Electrophoresis}

The separation of the plasma lipoproteins was improved by a combination of the procedures reported by Kahlke (12), Maguire et al. (13), and that recommended by the Beckman-Company. Within 1 hour, the lipoproteins of 16 plasma samples can be separated. The quality of separation is comparable to that reported by Maguire et al. (13). The influence of the alkaline glycerol solution on the agarose layer prior to drying the film guarantees excellent staining of the lipoprotein pattern. For the precipitation procedure with dextran sulfate- $\mathrm{CaCl}_{2}$, the use of any phosphate buffer has to be avoided in order to prevent the precipitation of Caphosphates within the agarose layer. Cutting of the opalescent lipoprotein fractions was accomplished more easily if a dark paper was placed under the plastic sheet. The results of the separation of the lipoprotein fractions by different procedures are shown in figure 2 . Sample B was dried with filter paper. The $\alpha$-fraction was, apparently, partially absorbed by the filter paper.

\section{Determination of cholesterol \\ in the presence of agarose}

With the earlier procedure (8), no influence of $\mathrm{HCl}$ on the cholesterol molecule or of agarose on the enzymatic reactions could be detected. In order to prevent dilution by the neutralized sample, solution $V$ was prepared by increasing the concentrations of solution 5 of the "Biochemica Test Combination Cholesterol" by a factor 1.5. This made the final test solution comparable to that described by Roeschlau et al. (10). However, the examination of the capacity of solution 5 revealed that a system consisting of $0.5 \mathrm{ml}$ neutralized sample and $2.0 \mathrm{ml}$ solution 5 showed the same kinetic properties as the original system (10) and the system previously described (8) (fig. 3). Accordingly, the replacement of solution $\mathrm{V}$ by the original formula of solution 5 (10) 


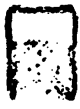

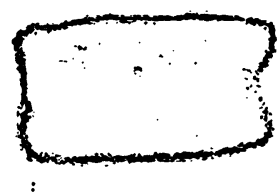

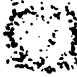

A

B

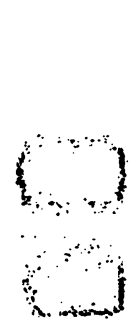

C

D

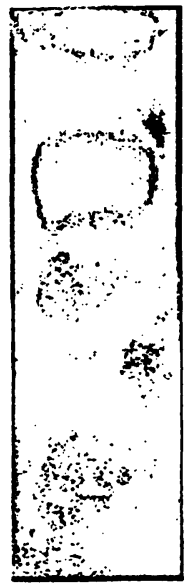

Fig. 2. Comparison of the electrophoretic procedures.

A. Corning-EEL/IMA-mi
lipid stain: Oil Red O.

B. Boscamp-microphor system; lipid stain: Sudan Black B.

Present system:

C. Lipid stain: Sudan Black B.

D. Precipitation with dextran sulfate- $\mathrm{CaCl}_{2}$ (11).

was feasible, thus making the present procedure more convenient for routine analysis.

Using this procedure, a linear relationship between cholesterol concentration and absorbance was found in the range of $0.75-25.6 \mathrm{mmol} / 1$ cholesterol (fig. 4). The coefficient of variation in the series (tab. 1) was $<1.5 \%$ for cholesterol concentrations $>3 \mathrm{mmol} / 1$ and $<3 \%$ in the lower range.

Influence of the hydrochloric acid on the ester bond of cholesterol esters

Plasma-agarose samples (control plasma and a mixture of hyperlipidemic plasma samples) were dried in vacuo and exposed to $\mathrm{HCl}$ for 5 minutes prior to further analysis. No influence on the ratio of free to total cholesterol was observed (tab. 2).

Tab. 1. Precision in the series.

$10 \mu \mathrm{l}$ cholesterol standard Preciset and $0.2 \mathrm{ml} 8 \mathrm{~g} / 1$ agarose solution were mixed and dried in vacuo $(n=10)$. This was followed by the procedure described in the text. Numbers in parenthesis: coefficients of variation (CV (\%))

\begin{tabular}{ll}
\hline $\begin{array}{l}\text { Cholesterol } \\
(\mathrm{mmol} / 1 \text { plasma })\end{array}$ & \\
\hline $25.6 \pm 0.11$ & $(0.4)$ \\
$19.3 \pm 0.09$ & $(0.5)$ \\
$10.6 \pm 0.03$ & $(0.3)$ \\
$5.47 \pm 0.04$ & $(0.7)$ \\
$2.89 \pm 0.04$ & $(1.5)$ \\
$1.43 \pm 0.03$ & $(2.2)$ \\
$0.75 \pm 0.02$ & $(2.8)$ \\
\hline
\end{tabular}

Tab. 2. Influence of hydrochloric acid on cholesterol esters. Precilip-agarose samples were dried in vacuo and dissolved in $6 \mathrm{~mol} / 1 \mathrm{HCl}$. The samples were exposed to $\mathrm{HCl}$ for 5 minutes $(n=4)$. This was followed by the procedure described in the text.

Control plasma: plasma of one child $(3.7 \mathrm{mmol} / 1$ cholesterol) (10).

Mixed plasma: equal volumes of plasmina samples from hyperlipoproteinaemias type IIa, type IIb and type IV were mixed (6.8 mmol/1 cholesterol) (10).

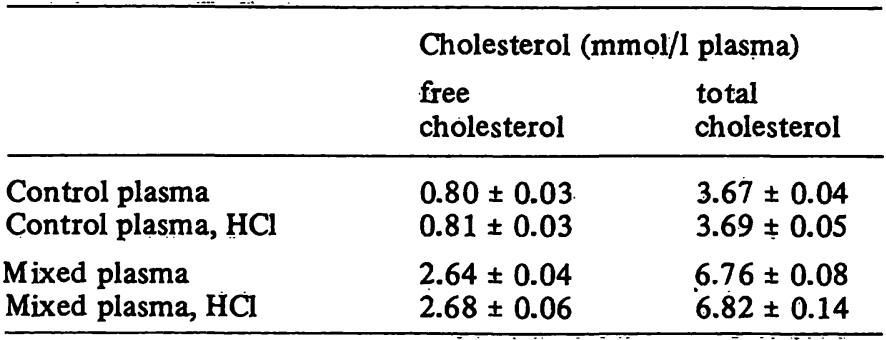
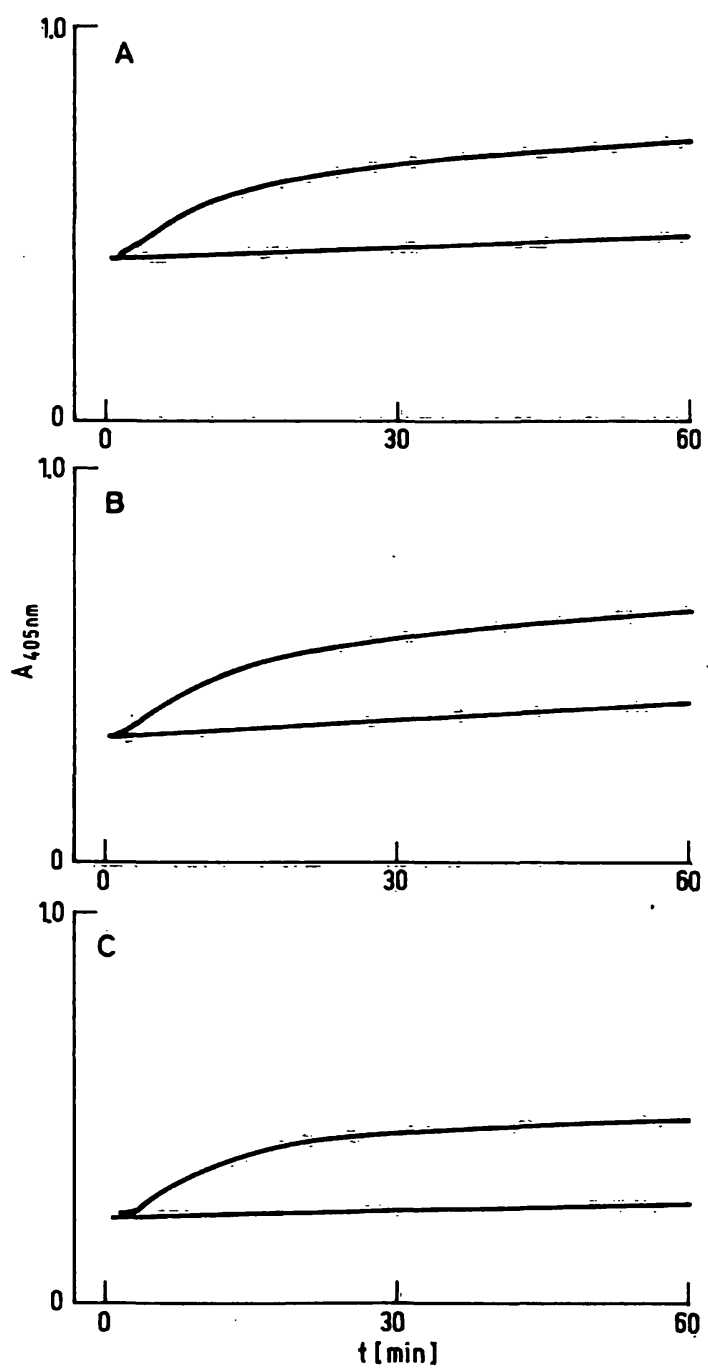

Fig. 3. Reaction curves.

Each sample contained $10 \mu$ Precilip $(3.76 \mathrm{mmol} / \mathrm{l})$ per $2.5 \mathrm{ml}$ test solution. The reactions. were initiated with cholesterol oxidase and recorded for one hour against the sample blank $(\mathrm{d}=2 \mathrm{~cm})$ at $405 \mathrm{~nm}$.

A: Determination of plasma cholesterol according to Roeschlau et al. (10); $\Delta \mathrm{A}=0.235$.

B: Determination of lipoprotein cholesterol according to Kupke (8); $\Delta \mathrm{A}=0.235$.

C: Present modification; $\Delta A=0.235$ 
Determination of cholesterol in plasma lipoprotein fractions

This improved method (fig. 3, c) was applied to the determination of cholesterol in lipoprotein fractions separated by electrophoresis on agarose gel (procedure b, tab. 3). As compared to the former "procedure a" (tab. 3) (8), no significant loss of cholesterol during the analytical steps was observed (recovery 95-100\%). The loss in "procedure a" was obviously due to drying the agarose film with filter paper. All lipoprotein fractions were subject to this loss; however, the $\alpha$-lipoprotein fractions of all plasma samples investigated showed the highest loss of cholesterol (fig. 2, b) (8). The present "procedure b" was found to be suitable for the quantitation of lipoprotein cholesterol with an adequate precision and detection limit (approx. $0.2 \mathrm{mmol} / \mathrm{l}$ ).

Examination of the plasma lipoprotein cholesterol of healthy children. -

A preliminary study

Plasma from heparinized capillary blood of 30 healthy (asymptomatic) fasting children was obtained. The total triacyl glycerols, the total cholesterol and the lipoprotein cholesterol were evaluated.

Among these children, 23 had a plasma cholesterol concentration $<4.66 \mathrm{mmol} / 1$ and 7 had values $>4.66 \mathrm{mmol} / \mathrm{l}$ (tab. 4). This cholesterol was mainly

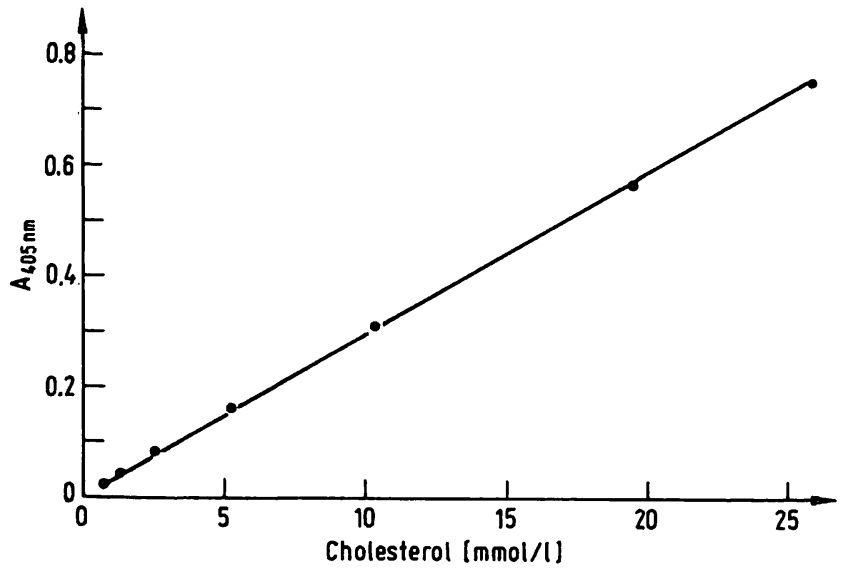

Fig. 4. Calibration curve.

Increasing amounts of the cholesterol standard Preciset and $0.2 \mathrm{ml} 8 \mathrm{~g} / \mathrm{l}$ agarose solution were mixed and dried in vacuo. The procedure was described in the methods. For each concentration: $\mathrm{n}=10$.

localized in the $\beta$-lipoproteins (fig. 5). No relevant age dependence of the cholesterol distribution patterns among the lipoprotein fractions was found. The cholesterol content of the $\beta$ - and $\alpha$-fractions was not affected by the elevated cholesterol of the group with cholesterol concentrations $>4.66 \mathrm{mmol} / \mathrm{l}$. Visual examination of the stained lipoprotein patterns in this group indicated a mildly developed Type II hyperlipoproteinemia. The plasma triacyl glycerol content of this

Tab. 3. Comparison of the present modification with that described previously (8).

Electrophoresis was carried out on three different plasma samples: healthy control, hyperlipoproteinaemias type IIb and type IV. After the end of electrophoresis, the agarose film was divided in two halves; one half was used for the present modification and the other half was subjected to the earlier procedure. Numbers in paren thesis: coefficients of variation (CV (\%)).

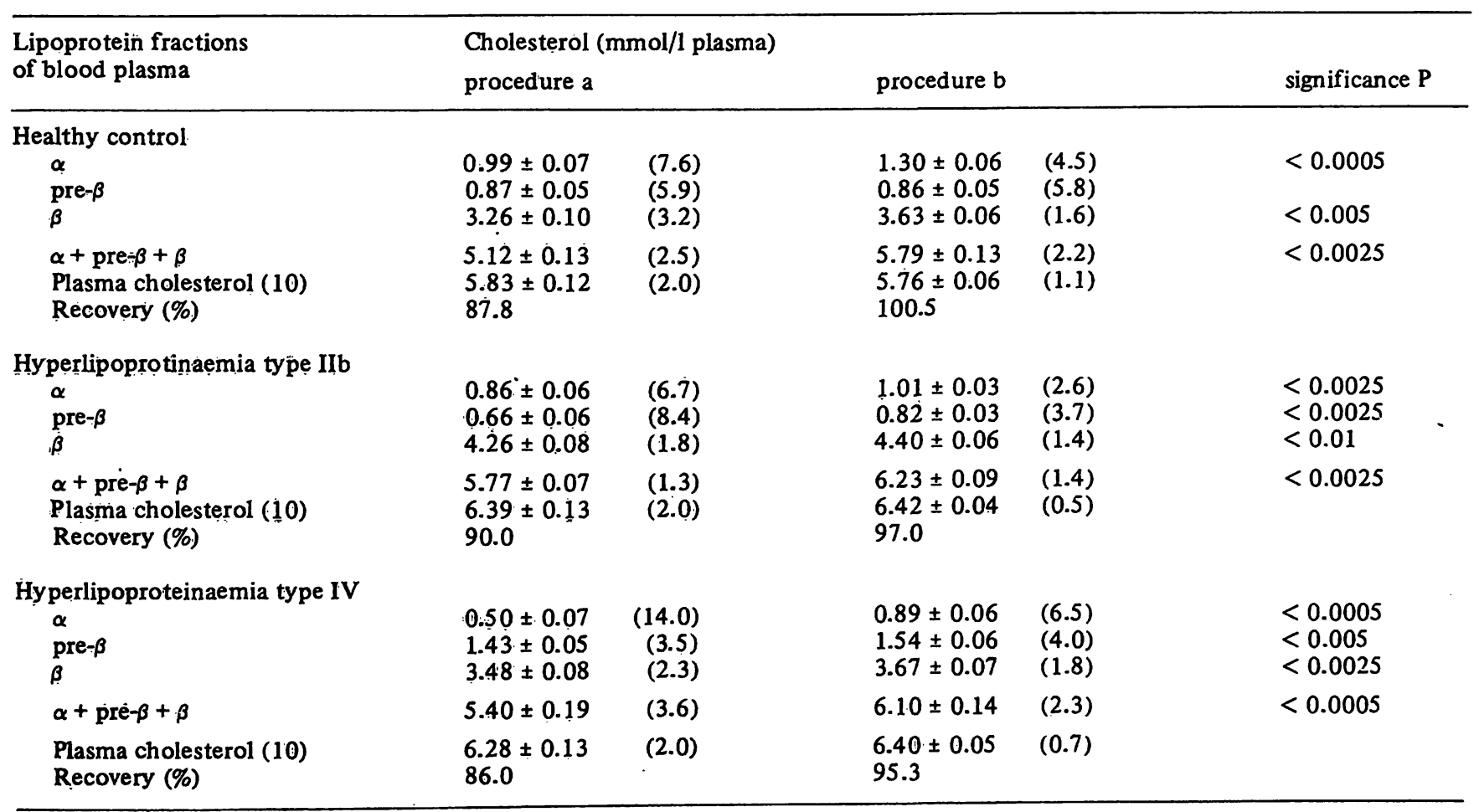


Tab. 4. Application of the present method to the examination of healthy children.

Plasma of heparinized capillary blood of 30 fasting children (1-15 years old) was analyzed.

$4.66 \mathrm{mmol} / \mathrm{l}=180 \mathrm{mg} / 100 \mathrm{ml}$ cholesterol $\mathrm{s}=$ significant

\begin{tabular}{llllll}
\hline Total cholesterol & $\begin{array}{l}\text { Triacyl glycerols } \\
(\mathrm{mmol} / \mathrm{l})\end{array}$ & $\begin{array}{l}\text { Cholesterol }(\mathrm{mmol} / \mathrm{l}) \\
\text { total }\end{array}$ & $\alpha$-Lipoproteins & pre- $\beta$-Lipoproteins & $\beta$-Lipoproteins \\
\hline $\begin{array}{l}<4.66 \mathrm{mmol} / 1 \\
(\mathrm{n}=23)\end{array}$ & $0.70 \pm 0.28$ & $3.62 \pm 0.60$ & $0.99 \pm 0.33$ & $0.37 \pm 0.21$ & $2.28 \pm 0.51$ \\
$\begin{array}{l}>4.66 \mathrm{mmol} / \mathrm{l} \\
(\mathrm{n}=7)\end{array}$ & $1.07 \pm 0.49^{\mathrm{s}}$ & $5.09 \pm 0.32^{\mathrm{s}}$ & $1.11 \pm 0.33$ & $0.35 \pm 0.14$ & $3.63 \pm 0.35^{\mathrm{s}}$ \\
\hline
\end{tabular}
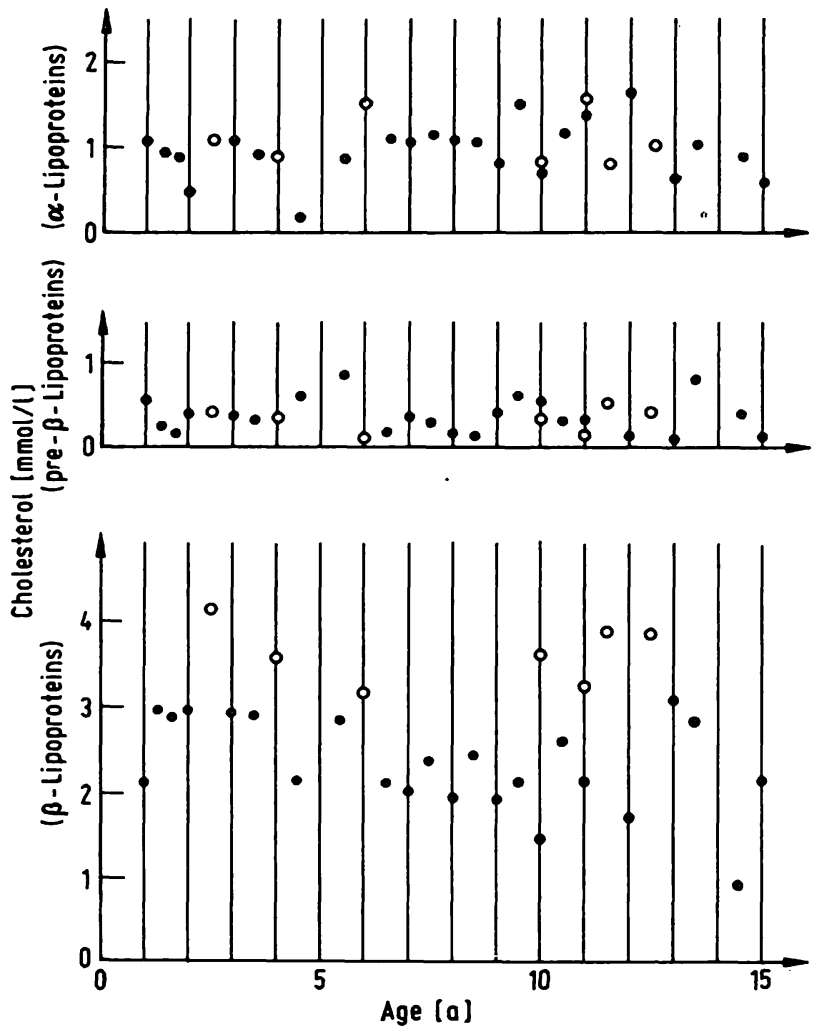

Fig. 5. Application of the present method to the examination of thirty healthy children.

The distribution of cholesterol among the plasma lipoprotein fractions is demonstrated. Data points located on the same vertical line pertain to one child. Total plasma cholesterol concentrations are indicated as follows:

$\bullet<4.66 \mathrm{mmol} / \mathrm{l} \quad \circ>4.66 \mathrm{mmol} / \mathrm{l}$.

\section{References}

1. Kannel, W. B. \& Dawber, Th. R. (1972), J. Pediatr. 80 , 544-554.

2. Mitchell, Sh., Blount, S. G., Blumenthal, S., Jesse, M. J. \& Weidman, W. H. (1972), Pediatrics 49, 165-168.

3. Glueck, Ch. J., Tsang, R. C. (1972), Am. J. Clin. Nutr. 25, 224-230.

4. Glueck, Ch. J., Fallat, R. W. \& Tsang, R. (1974), Am. J. Dis. Child. 128, 569-577.

5. Kwiterovich, P. O. (1974), Pediatrics 53, 455-457.

6. Berenson, G. S. (August 24-28, 1976), "The IV th International Symposium on Atherosclerosis" (Plenary Session), Tokyo, Japan.

7. Levy, R. I. \& Rifkind, B. M. (1973), Am. J. Cardiol. 31, 547-556. group was also higher than that of the group with plasma cholesterol $<4.66 \mathrm{mmol} / \mathrm{l}$.

The fact that $23 \%$ of the children in this small sample had a cholesterol level $>4.66 \mathrm{mmol} / 1$ suggests the possibility of an underlying lipid abnormality (1). This high percentage may well reflect the situation of children living in an industrial urban environment (4) like Düsseldorf.

At present, large groups of children of kindergarten age and of juvenile diabetics are under investigation.

\section{Conclusions}

The procedure described in this report is simple and precise. It is suitable for the quantitative enzymatic determination of cholesterol in plasma lipoprotein fractions separated by electrophoresis on agarose gel. The application of this method to the examination of a small group of healthy children must be regarded as a preliminary model for large-scale studies in the field of pediatrics.

\section{Acknowledgement}

We are grateful to Dupont de Nemours \& Co. Inc., Wilmington, Delaware, USA for a generous supply of plastic sheets, Cronar Type P-7R.
8. Kupke, I. R. (1976), this J. 14, 217-223.

9. Heuck, C. C., Nothelfer, A. Raetzer, H. \& Schlierf, G. (1977), J. Lipid Res. 18, 259-263.

10. Roeschlau, P., Bernt, E. \& Gruber, W. (1974), this J. 12, 403-407.

11. Wieland, H. \& Seidel, D. (1973), Clin. Chem. 19, 11391141.

12. Kahlke, W. (1974), in "Serumproteine", p. 105-110 (Englhardt, A. \& Lommel, H., eds.) Vèrlag Chemie, Weinheim, Bergstraße.

13. Maguire, G. F. \& Breckenridge, W. C. (1975), Clin. Biochem. $8,161-168$.

Priv.-Doz. Dr. Ingeborg Kupke Medizinische Einrichtungen der Universität Düsseldorf Kindèrklinik

Moorenstraße 5

D-4000 Düsseldorf 